\title{
ADONIS REVISITED: EROTIC REPRESENTATIONS OF THE MALE BODY IN WOMEN'S CRIME FICTION
}

\author{
Brigitte Frizzoni
}

\begin{abstract}
If we take a close look at representations of the male body in popular culture, John Berger's famous phrase "Men look at women, and women watch themselves being looked at" no longer seems appropriate. Not only in the visual media, but also in popular literature male bodies are presented in increasingly eroticised ways, hence making them available for the female gaze and female desire. This shift, or "disruption of conventional patterns of looking", as Rosalind Gill observes, and the representation of maleness in popular culture and everyday life in general, has attracted much scholarly attention in recent years. While visual media such as films and advertising have already been discussed, in this respect women's crime novels remain to be examined closely. These texts have boomed in the international book market during the past two decades and are characterised, among other aspects, by disrupting conventional patterns. In my paper, I shall argue that eroticised representations of the male body are a striking feature of many women's crime novels, leading to a new type of character, the Adonis, the beautiful, erotic male - often as an homme fatal, a lethally attractive male - and that erotic tension, triggered by these representations, is crucial to the genre's typical form of suspense in some of the most popular examples.
\end{abstract}

Key words: female desire, female gaze, gender, male beauty, male body, masculinity, men in popular literature, popular culture, suspense, women's crime fiction

Over the last decades a remarkable change has taken place in the representation of men in Western popular culture: Male bodies are presented in increasingly eroticised ways which allow them to be looked at from a female point of view. A well-known example is the Diet Coke ad from 1994, where women queue up at eleven thirty in excited anticipation to marvel at the toned body of the construction worker outside, as he takes off his T-shirt and drinks a Coke (Kaplan 2002). ${ }^{1}$ Lucky Vanous, the male model, created excitement not only in the advert, but also outside this text as well. Soon referred to as Diet Coke Hunk in public discourse, he graced the cover of Psychology Today in Novem- 
ber 1994 for an article titled 'The Beefcaking of America'. The piece discussed the reasons for this remarkably new "acceptance of men as sex objects, men as beautiful" and the "seismic shift in male body image" (Neimark 1994: 34).

\section{ADONIS CULTURES - MEN AS OBJECTS OF DESIRE}

It is not so much the presentation of the Diet Coke Hunk body as beautiful and desirable that is new. According to anthropologist David Gilmore (1994: 197), there is consistent evidence that in many cultures the physical beauty of the male is (and has been) as important as that of the female, and sometimes even more important. Striking examples are found in Sahelian cultures from Mauritania to Kenya. Among them is the Wodaabe tribe, a Muslim people living in the Bornu Emirate of northeastern Nigeria, who stage male beauty contests with female judges. This is an 'Adonis culture' where beauty is the main measure of a man's social worth, and where it is the men, not the women, who are the objects of erotic desire (Gilmore 1994: 197-202). Compared to Gilmore's description of this beauty contest, the presentation of the Diet Coke Hunk is far tamer and not exactly 'new'. However, that male beauty and appearance are of crucial importance to both men and women, has been largely elided in Western culture, Gilmore argues, “for reasons of cultural bias: woman's culturally induced inhibition about expressing her sexual desires openly and man's equally culture-bound anxiety about appearing 'vain' (that is, effeminate)" (Gilmore 1994: 206). These inhibitions, anxieties, and restrictions have obviously been eased considerably during the last decade.

Indeed, the Diet Coke ad is one of many examples, beside earlier erotic male 'landmarks' in popular culture, such as John Travolta in Saturday Night Fever (1977), or the Chippendales, who took the stages in the 1980s. Similar 'exhibitions' may also be found in the Rock and Pop scene, for instance in Mick Jagger's stage shows. A 1983 Calvin Klein ad provoked a debate by depicting Olympic pole vaulter Tom Hintnaus in underwear with clearly pronounced penis (Bordo 1999: 181ff). What is effectively new is the frequency and explicitness of such representations, the fact that erotic men are handed to the female (and male) audiences "on a silver platter", as Susan Bordo (1999: 179) notes. More telling still is the way in which the male body is stylised and how the counterpart of this erotic staging positions itself. In this respect, the representation of erotic maleness in Western popular culture achieves a new quality manifesting itself through a profound change in ways of looking or, respectively, subject and object positions (Simpson 1994; Gill, Henwood \& McLean 2005: 38). This is also evident in the previously mentioned Diet Coke ad: it is 
striking by how explicitly it depicts the women's enjoyment and desire, and by virtue of the remarkable change in that the male now positions himself as a desirable object (see also Gill, Henwood \& McLean 2003; 2005). This is even more pronounced in a Diet Coke television spot thirteen years later: While Lucky Vanous in 1994 is not yet aware of the desiring female look, the 'new hunk' in 2007 now consciously presents himself as an object of female desire and amusedly enjoys his objecthood. ${ }^{2}$

John Berger's (1972: 47) dictum, "Men look at women. Women watch themselves being looked at", no longer seems fitting. Women look at men, men observe (indeed enjoy) being looked at - now the reverse thesis is a more accurate description of the current situation. Laura Mulvey's theory of gender-specific ways of looking in mainstream Hollywood cinema from the 1970s, according to which the viewer's look is constucted as male and the object of the look as female, no longer seems to hold (Mulvey 1988 [1975]: 57-68). The 'tobe-looked-at-ness', which Mulvey in the 1970s exclusively designated to the female position, is now also true for men (Mulvey 1988 [1975]: 67; cf. Doane 1985; Dyer 1986; see also the overview of spectatorship theories in Mayne 1993). Women as 'bearers of the look' and men as 'objects of the (female and male) gaze', as they are humorously depicted in the Diet Coke spots, have in the meantime become quite common.

These changing conventions of looking and shifts in male body imagery have in recent years attracted much scholarly attention. Sociologist Rosalind Gill points out a number of trends and social movements that may have helped to produce this shift in the representation of maleness in popular culture and everyday life, the most important being feminism and the gay movement. Both had a transformative effect on popular culture. One result, for example, was the rise of popular subgenres, such as the women's crime novel discussed here, or the gay and lesbian crime novel. "It is within the gay media that representations of men as erotic objects [...] were first produced," Gill notes.

Over the past decade, gay media have become more mainstream, realising that such representations were also desirable outside of the gay subculture (Gill 2001: Session 2). ${ }^{3}$ Film and literary scholar Kenneth MacKinnon suggests that this mainstreaming occurred because of consumer capitalism. According to MacKinnon, the latter is an important motor behind this new setting of the female gaze and the (secret) male pleasures of object position, exhibitionism and narcissism. In order to fulfil its expansionist intent, consumer capitalism adopts an equal-opportunities policy by commodifying the sexes and exploiting feminist and gay politics. Advertising objectifies and feminises both men and women. MacKinnon (1997: 191; 2003: 100) hence refers to the male as erotic object as a somewhat "uneasy pleasure". 
Interestingly, as Gill and others (Gill 2001: Session 2) point out, men's bodies are represented "in a very specific generic style". They are mostly white, young, muscular, slim, clean-shaven, "both hypermasculine and strangely feminine" (Neimark 1994: 34), with facial features that connote a combination of both softness and strength: strong jaw, full lips, big eyes, and soft clear skin. These images are interesting with respect to what they reveal about "contradictory expectations about men", as Gill notes: these 'new men' have to be masculine and strong, but also emotional, nurturing, and caring (Gill 2001: Session 4; Doty 1996: 280-284).

The erotic objectification of the male as well as the imagery of erotically coded male bodies in the visual media have also influenced popular literature. It should come as no surprise that it is to be found in romance novels, where the description of desirable Prince Charmings is constitutive of the genre. In fact, the increase of explicit erotic descriptions of the male body in romance since the 1980s is quite striking. A number of specifically labeled erotic series have been published in the last twenty years (Sonnet 1999; Scherreiks 2003; Thiel 1991; Radway 1991 [1984]; Modleski 1982). Allison Assiter (1988) has referred to these texts as 'porn for women'. According to Carol Thurston (1987: 7), they constitute the first major body of light fiction in which women write for women about sexuality.

However, men as erotic objects are not only to be found in 'porn for women', but also in women's crime novels that for the last two decades have been booming in the international book market. These books are written by women, influenced by second-wave feminism, and dominated by skilled female investigators well aware of gender issues.

In many of these crime novels the handsome male, the Adonis, now is a principal character type, as shall be demonstrated with reference to both one successful British and American series: Lauren Henderson's Sam Jones books and Janet Evanovich's Stephanie Plum fiction. Both series started in the mid1990s and have been translated into several languages, hence also establishing themselves internationally. Both authors are well-versed in the depiction of erotic scenes. Prior to her crime books, American writer Janet Evanovich published romance novels, which in the wake of the Stephanie Plum series' commercial success have been re-issued; Briton Lauren Henderson has penned contributions to the sex magazine Erotic Review and also writes romance novels and guidebooks.

The two series will be scrutinised from different angles: central to the analysis of Lauren Henderson's handsome males will be their staging in comparison with the visual representations mentioned above: Do the erotic men lend themselves to the female gaze in a similar way to that of the visual media? With 
Evanovich, by contrast, the examination will focus on the potential of her murderously beautiful male characters for suspense and the dramatic possibilities they allow for.

\section{'PRETTY BOY’ AND ‘GENDER-BENDER' - EROTICALLY CODED MALES IN LAUREN HENDERSON'S MYSTERY SERIES}

Lauren Henderson's seven-volume series ${ }^{4}$ centres on sculpturer and amateur sleuth Sam Jones, who lives in London. Henderson calls her crime fiction tart noir, and her heroine tart. On the webpage shared by her with Stella Duffy, the term is explained as follows:

Tart. It's a potent four-letter word. Sweet, sour, sharp, sexy, bad, with a touch of cheesecake. It seemed to sum up the detectives in our segment of the crime fiction genre, the independent-minded female sleuths who are tough enough to take on thugs and corrupt cops, tender enough to be moved by tough, tender men (or women, as the case may be). These are neofeminist women, half Philip Marlowe, half femme-fatale, who make their own rules, who think it's entirely possible to save the world while wearing a drop-dead dress and four-inch heels. ${ }^{5}$

Noticeable is the protagonists' explicit positioning as "neofeminist women". Born in 1966, Henderson and Duffy implicitly distance themselves from the second-wave feminism of the 1960s through 1980s. Their tart noir sleuths consider themselves representatives of 'power feminism' (concerning 'power' v. 'victim feminism' see Gillis \& Munford 2004: 167, 172), which suggests markedly changed subject and object positions.

This is confirmed by Henderson's most recent Sam Jones novel, Pretty Boy (2001). Here - nomen est omen - the female look's object of desire is just such a handsome youth:

The dark hair fell back from his face. Immediately, I sat up straight in my chair. The sight of him had had much the same effect on me as the idea of ice cream had produced on the children. [...] Alan's thin frame was made to be filmed in black and white, stretched across a sofa in a semi-transparent shirt, [...] his sheer, drop-dead beauty was taking my breath away. [...] He had to be in his early twenties [...]. He really was exquisite [...]. His colouring was Snow White's: coal-black hair and eyes, a full red mouth, which probably embarrassed him severely, and that pale, pale skin. [...] "Darling," Hugo muttered to me crossly, "your mouth 
is hanging open. Could you shut it, please? You look like a dull-witted country bumpkin." (Henderson 2001: 54-58)

The protagonist's look both appraises and admires the pale-skinned, fragile, and feminine body of Alan, the 'pretty boy'. His body is that of an adolescent, not of an adult. In the history of the 'publicised' male body there is, as William G. Doty has shown (1996: 281), a tradition of idealising the adolescent physique, The 'pretty boy' represents the ideal of androgyny which is based on the idea of the 'integral person', a concept in humanistic psychology popular in the 1980 s that contributed to the change in the representation of men and women (Gill 2003: 43; Gill 2001: Session 2).

Pale-skinned, young, slim, hairless, and with soft, full lips, Alan's physicality corresponds with central aspects of the male body's iconography of the 1990s as described above. But it is also strikingly different from the concept of erotic manliness, as it clearly lacks 'hyper-masculinity'. Hence also Alan is revealed to be an unsuitable partner for Sam. After a 'one-night stand' she notices that he just does not smell right, "thin and reedy [...] which meant that our chemistry was off" (Henderson 2001: 293). The words "thin and reedy" explicitly criticise Alan's lack of 'hyper-masculinity'. Thus, the combination of femininity and hyper-masculinity, that sine qua non in the pictorial representation of the male body, is crucial here.

The text passage quoted from Henderson's Pretty Boy is also instructive as to its ironic commentary on the gaze, because the protagonist, Sam, while looking is in turn being looked at by her partner Hugo. Ironic commentary and parodic reversal are frequently employed means in female crime fiction in negotiating gender stereotypes.

Elsewhere, Sam now contemplates Hugo with great aesthetic pleasure:

His skin was smooth and almost hairless, like a marble statue, and he had the firm high buttocks of a David - Michelangelo, not Donatello - or the Rodin I had seen in the Sculpture Garden at the Met in New York, the Three Shades. Being still erect, however, he had the advantage on practically any statue I had ever seen. [...] "Someone ought to sculpt you like that," I observed. He turned to look at me. "You're always objectifying me," he said. "Quite literally in this case." "Wish I could. What a shame I'm not representational. I'd get a nice slab of marble and start carving." (Henderson 2001: 3ff)

The object of the female gaze, Hugo, changes his status of 'being-looked-atness' (Mulvey 1988: 67) by humorously commenting on it, and the female 'bearer of the look', Sam, readily takes part in it. The (word-)play between 
Hugo and Sam is an exchange between equals who know each other very well - actually, Sam and Hugo have been lovers for quite some time, since the fourth title of the series, Freeze My Margarita (Henderson 1998). Hugo is presented as an attractive partner neither only due to his physical qualities nor simply because he mocks female curiosity, but above all because he enjoys it. This is illustrated by a text passage from the fourth volume, Freeze My Margarita, in which Sam and Hugo get closer. They are not yet lovers; for the first time, Sam is at Hugo's place, he serves his guest tea and biscuits and then excuses himself to take a quick shower:

After about ten minutes, Hugo emerged from the bathroom [...]. Then, as if he had come to some decision, in one slow, leisurely movement he untied the dressing gown and let it fall at his feet. He was quite naked underneath, as was only to be expected. "Do you like what you see?" he enquired, his tone of voice level and matter-of-fact.

If there had been the least hint of campness, of coquetry, I would have recovered from the shock and made some equally flirtatious remark. But there wasn't, and so I remained absolutely speechless, staring at him, at the long narrow muscles of his thighs, the set of his shoulders, the faint golden glow of his pale body in the light from the window. A small, still-rational part of my mind observed that he did have calves, and registered approval. My mouth was dry. (Henderson 1998: 152ff)

Hugo actively evokes the female look and stages himself as an object to be gazed at. In Freeze My Margarita he is literally and metaphorically introduced as an actor, as someone who likes playing with gender identities. He is less androgynous than the 'pretty boy' and corresponds to the iconographic representation of the male in the visual media, with a muscular body and feminine traits. He enjoys taking foam baths, body lotions, and perfumes, and is hence, as Sam observes at one point, "much more a girl than me" (Henderson 2001: 4). In the media discourse of the 1990s the term 'metrosexual' has emerged to describe this kind of male, an abbreviation for "metropolitan heterosexual" (Simpson 1994). According to Mark Simpson, a metrosexual male is an urbanite with a pronounced aesthetic sense who invests time and money in his appearance and is not afraid to be appraised as vain or homosexual. He is a 'mirror man', someone who has internalised the controlling look into the mirror, a 'gender-bender', who crosses the boundaries between man and woman, homoand heterosexual orientation, and who obviously enjoys being the object of the female gaze. However, the gain of knowledge through the coining of such terms has also been criticised (Urbauer 2005: 95), and Mark Simpson himself in an article of 2003 ridicules the widespread use of his expression since 1994, which 
he still encounters regularly a decade after and now considers "memorably silly" (Simpson 2003). Nevertheless, representations such as those of Sam and Hugo attest to markedly changed gender positions. Such shifts, however, are accompanied by insecurities which in turn are picked up by female crime fiction, as will now be examined with respect to Janet Evanovich's series of bestsellers.

\section{'HOMME FATAL'AND 'MR. RIGHT NOW': JANET EVANOVICH'S MURDEROUSLY EROTIC MALES AND THEIR POTENTIAL FOR SUSPENSE}

The Adonis, the erotic male, proves to be highly productive of suspense in the female crime novel. One development of this new character type is the homme fatal - the dangerously attractive man as counter-image of the femme fatale, at whose first appearance the reader immediately asks herself: Is this object of desire to be trusted? Could that be the murderer? In both senses of the word, this alarmingly attractive male is encountered by the crime heroines in two distinct forms: In the narrower sense - and overall more typical of the crime genre and its suspense -, he is a character who threatens the bodily integrity of the heroine, which she, blinded by his physical beauty, becomes aware of (too) late. Characteristic of Janet Evanovich's series, however, is the homme fatal in another sense, in that he does not endanger her life but represents a "dangerous" erotic seduction. In Too Many Blondes, Lauren Henderson, too, uses the term similarly: "Derek was an homme fatal. Women would be fighting over him for the rest of his life, and he knew it." (Henderson 2002 [1996]: $254)^{6}$

\section{Playing with the homme fatal}

The two homme fatal conceptions can be combined. Due to the professional suspiciousness of the investigating heroine doubts about a handsome man's capability for relationships may quickly give way to doubts about his basic integrity. This wavering between real and imaginary dangerousness makes the character of the homme fatal in female crime fiction particularly attractive from a dramatic point of view. In this respect, each subgenre proceeds differently. While Susanna Moore's psychological thriller In the Cut takes the motif of the "lethal male" literally (Moore 2003 [1995]), and the female protagonist 
precipitates to her doom precisely because of a suspicion finally revealed to be mistaken, Janet Evanovich's crime novels play humorously with the "potential dangers" of the homme fatal.

So far her series consists of fifteen books. ${ }^{7}$ Stephanie Plum is a "bounty hunter" who works and lives in Trenton, New Jersey. Two male characters provide suspense in the Plum series, present from the first volume. As Stephanie Plum explains:

I've got two very hot guys in my life, and which one is the one depends on when you ask me. They're both Mr. Right. And they're both Mr. Wrong. They're both a little scary in a good way. (Evanovich \& Yalof 2006: xv)

This characterisation and the fact that we are dealing with characters in a series clearly indicates that one has to reckon with erotic difficulties but not the threat to life and limb.

One of either men is the Cuban-American Ranger. Combining sexual attraction with ethnicity increases the erotic potential through the allure of the exotic, the 'other'. Connotative linking of dark skin and sex appeal is a stereotype of popular culture. Additionally, the erotic promise of suspense is intensified by hyper-masculine traits. Hence a marked difference to the 'new men' in Laura Henderson's novels becomes apparant. The representation of desirable manhood in Evanovich's work corresponds to the empirically identified preferences of the female readership of romance. According to a survey by the Romance Writers of America from 2004, the three most important and desired traits in heroes are, in this order, muscles, good looks, and intelligence (Romance Writers of America Inc. 2004). Ranger ideally fulfils all three requirements and has muscles "like they'd been carved out of granite [...] and a don'tmess-with-me-body" (Evanovich 1994: 31).

Through such descriptions Ranger is positioned as an object of female curiosity and erotic desire; for the female protagonist he primarily embodies

[s] exual satisfaction. Beyond that I'm not sure. I gave an involuntary shiver at the thought of a sexual encounter with Ranger. I know so little about him that in some ways it would be like making love blindfolded [...] pure sensation and physical exploration. (Evanovich 2001: 280)

This reveals the typical ambivalence of the erotic male with homme fatal qualities. The reference to a lack of knowledge about the erotic object (in the seventh volume of the series!) or the image of being blindfolded indicate that the devised erotic scenario represents an exciting adventure. Such directions stimulate a highly involved mode of reading perceptive to 'telling' details and erotic 
signals, and an intensified gaze indispensable to the successful creation of suspense.

The lack of information evident in this example and the theme of losing control - "making love blindfolded" - are crucial to the modeling of a literary character with homme fatal potential. Accordingly, Ranger is depicted as an obscure, autonomous character: "Ranger was a cat. Quiet. Every muscle relaxed on command. Probably did yoga. Might not be human." (Evanovich 2002: 143) The image of the predatory cat employed by the first-person narrator, the black panther - Ranger's trademark being a black outfit -, represents the character type of the 'dangerously' erotic male the female sleuth is magnetically drawn to:

He moved against me and desire skittered through my stomach and burned low in my belly. He was hard everywhere. His thigh, his gun... everything was hard. [...] I had my hands splayed over his chest, and I felt the toned muscle under my hands, felt his heart beating. So he has a heart, I thought. That's a good sign. He must be at least part human. [...] He kicked his boots off, dropped his gun belt, and he stripped. The light was low, but it was enough to see that what Ranger promised in [...] clothes was kept when the clothes were shed. He was all firm muscle and smooth dark skin. His body was in perfect proportion. His eyes were intense and focused. [...] And then suddenly he was inside me. He once told me that time spent with him would ruin me for all other men. When he said it, I thought it was an outrageous threat. I no longer thought it outrageous. (Evanovich 2002: 226ff, emphasis in original)

Striking about this scene is also a distinctive double perception. On the one hand, the first-person narrator pays very close attention to what she feels and sees; on the other, she distances herself, observing and commenting on the interaction from the outside. By reflecting on the experience she retreats from the event and is not absorbed by the homme fatal. This distancing is also expressed through the humorous description which simultaneously defuses the exoticism that in a different context could be read as racist and sexist.

Elsewhere, Ranger is endowed with characteristics which ensure his trustworthiness and counteract an homme fatal perception: Not only is he erotically appealing, but also helpful, loyal, dependable, paying attention to clothing and nutrition, as well as having a sense of family. Thus hyper-masculinity combines with qualities connoted as 'feminine'; obviously, the image of the 'new man' - within more conventional conceptions of masculinity - has left its traces in the American culture also.

The particular allure of the play with the erotic male as potential homme fatal especially consists in the texts offering multiple possible readings: the 
reader may adopt an involved reading position, imaginarily engaging with the protagonist in erotic encounters, or, in negotiating meanings, concentrate on ironic elements which reveal the homme fatal to be a construct.

This possibility of a 'double' reading is another reason why the erotic male as homme fatal has firmly established himself in female crime fiction since the 1990s.

Janet Evanovich's series also demonstrates how the suspense related to the presence of the 'murderously' erotic men may be secured in the context of an ongoing serial.

\section{Serial eroticism: from 'Mr. Right' to 'Mr. Right Now'}

Ranger is only one of the two "very hot guys" in Stephanie Plum's life, between whom she is torn - which already suggests the basic structure of Evanovich's serial eroticism. The way in which investigative and romantic story lines are interwoven and weighted has in the reception of her novels repeatedly become the object of discussion among readers; their reactions suggest that the romantic story line often attracts greater interest than the crime plot.

For crime novels conceived as a series, the love story poses a problem which has been discussed on the crime mailing list DorothyL under the heading 'Will They or Won't They?': The more emphasis a series places on an evolving erotic relationship of the protagonist as motor of suspense, the greater the danger that it loses its payload once the sexual act has taken place. It therefore suggests itself to postpone such turning points in the heroine's romantic story line. Which is also the case with Evanovich's series. The 'first time' between Stephanie Plum and Ranger cited above does not take place until the eighth volume of the series - although already from the first volume on it repeatedly almost takes place, preferably towards the end of the book in question, as a deliberately placed cliffhanger designed to make readers buy the following title in the series.

This procedure can be quite tricky, however. It not only requires inventive plotting in order to avoid seeming schematic - an impression almost unavoidable by the third instance of deferring the sexual act; every postponement also leads to an increase of expectations in case the intimate encounter finally takes place. Thus, one of Evanovich's readers expressed her disappointment:

I was initially really annoyed at the lack of detail in the sex scene with Ranger. I couldn't figure out how, after that, she was going to make up for glossing over something we've been waiting for throughout seven other books. (DorothyL, Subjekt: EVANOVICH SPOILER - HARD EIGHT - SPOILER, 27 Jul 2002) 
Another discussion thread within the crime community focuses on feasible alternatives to the 'series-endangered' first intimate meeting of the protagonist and her partner. "They finally 'did it' and the anticipation was no longer there. I know it can kill a TV series (Moonlighting)", one contributor notes. The advice given to writers of series, with Evanovich in mind: "Some writers keep the tension building by throwing in a triangle (Stephanie \& Joe \& Ranger) and then that splits readers into pro-Joe and pro-Ranger camps." (DorothyL, Subjekt: Will They or Won't They?, 8 July 2003)

The triangular relationship proposed here is in fact the basis of the erotic tension throughout the entire Stephanie Plum series. Joe (Morelli) is the second representative of erotic manliness. Having two erotic male characters allows for greater dramatic possibilities in varying the romantic action crucial to Evanovich's series. For this the contenders for the heroine's favours must be characters on a par, which automatically draws them closer together; at the same time, they must also be different enough from one another.

Joe Morelli also meets the demands of the romance readership - he is intelligent, of muscular build, and exudes great sex appeal. His character is obviously so attractive that in contemplating the ideal casting of his role in a potential film adaptation of the novels one of the readers on DorothyL enthused:

Joe Morelli - Val Kilmer. Mmm. Dark hair. A combination Batman and The Saint exuding a brooding sexuality ... (sighs, and returns from blissful contemplation to the present) Where was I? (DorothyL, Subjekt: Casting Plums, 28 Aug 2003)

Like Ranger, Joe Morelli has the homme fatal ability to ruin a woman's life, as Stephanie Plum observes at the beginning of the first volume: "There are some men who enter a woman's life and screw it up forever. Joseph Morelli did this to me - not forever, but periodically." (Evanovich 1994: 3) Just like his competitor, he appears to her as a "force of nature"; she characterises him as a comet which "once every ten years gets sucked into my gravitational pull, furiously circles me, and then rockets back out into space and our needs never seem to be in total alignment" (Evanovich 2001: 280).

Besides these similarities Evanovich provides her second 'beauty' also with sufficient individuality. While he is an investigator, too, as a policeman he more unambiguously represents law and order than Ranger, who often sails close to the wind. Although Joe is sometimes also troubled by too much closeness, he is socially far more affable than Ranger. Originating from an Italian family clan, he enjoys the company of others. With his dog he lives in a house, cosy and with a garden, inherited from his aunt. His masculinity is associated with qualities such as warmth, humour, and a sense of family. This would 
make him seem virtually predestined for the role of 'Mr. Right' - if this were not opposed by the dramatic reasons given above. Hence, the protagonist's unwillingness to choose between the two men structures the whole series: "It was like choosing between birthday cake and a big-boy margarita" (Evanovich 2005: 8). Therefore the series keeps alternating between the two male characters, there is no longer a 'Mr. Right', but only (an alternating) 'Mr. Right Now'. Not the least to maintain the series' suspense, one of the romantic genre's main conventions is suspended (Harzewski 2006: 37 speaks of 'Mr. Maybe').

The variations on the Adonis character as 'pretty boy', 'gender bender', 'homme fatal' and 'Mr. Right Now' reveal a distinctive change in the female crime novel. In many texts created in the context of the second feminist movement, female desire and sexuality are conceived as being highly problematic in a male-dominated culture. Female sexuality was taken as "the locus of unequal heterosexual power relations": main topics of the early texts often focused on domestic violence, incest, rape, sexual harassment and restricted personal freedom to walk the streets (Vance 1992 [1984], cited in Sonnett 1999: 172). ${ }^{8}$ In the texts of the 1990s however, female desire is liberated from these burdens. Female desire, the female gaze at the erotic male is no exception but the rule. Indeed, women also look, and they thoroughly enjoy doing so.

Such displacements, however, always also imply insecurity; ${ }^{9}$ acting out newly won freedoms is limited by the fear of losing control of one's libidinal drives, which is narratively enacted through the character type of homme fatal. In this way, women's crime fiction also contributes towards society's self-understanding with respect to the changing gender positions.

\section{NOTES}

${ }^{1}$ Currently on YouTube, see http://www.youtube.com/watch?v=TdrE1VmxzoE, accessed on 20 Nov 2009.

${ }^{2}$ Currently on YouTube, cf. http://www.youtube.com/watch?v=4uL-YMCJIRY, accessed on 20 Nov 2009.

3 This online seminar by Rosalind Gill is partly based on an empirical study about men's relationship with their bodies. Together with Karen Henwood and Carl McLean, Rosalind Gill interviewed 140 young men between 15 and 35 throughout the UK, men of different class, racial and ethnic background, and sexual orientation.

4 Dead White Female (1995); Too Many Blondes (1996); The Black Rubber Dress (1997); Freeze My Margarita (1998); The Strawberry Tattoo (1999); Chained! (2000); Pretty Boy (2001). 
5 See http://www.tartcity.com/intro.html, accessed on 20 Nov 2008.

6 To my knowledge Lauren Henderson is the first to use this expression. This character's centrality in women's crime fiction is also evidenced by different researches that independently from one another use this term. Walton \& Jones 1999: 126 explicitly claim copyright to the coinage, despite Dietze already employing it in 1997: 243-247. Henderson, in turn, had already used it one year prior to Dietze.

7 One for the Money (1994), Two for the Dough (1996), Three to Get Deadly (1997), Four to Score (1998), High Five (1999), Hot Six (2000), Seven Up (2001), Hard Eight (2002), To the Nines (2003), Ten Big Ones (2004), Eleven on Top (2005), Twelve Sharp (2006), Lean Mean Thirteen (2007), Fearless Fourteen (2008); Finger Lickin' Fifteen (2009).

${ }^{8}$ Vance's essay presents a historical review of second-wave feminism's "troubled relation with women's sexuality in male-dominated culture". Examples of detective novels dealing with sexuality as locus of unequal power relations are: Barbara Wilson's The Dog Collar Murders (1989); P. M. Carlson's Murder Misread (1990); Lauren Wright Douglas's The Daughters of Artemis (1991).

9 The appearance of the femme fatale in film noir may be considered a comparable case, which is interpreted as a reaction to changing gender relations and the concomitant effect of male insecurity, see Dietze 1997; Place 1980; Dyer 1980; Kaufmann 1997.

\section{REFERENCES}

Assiter, Alison 1988. Romance Fiction. Porn for Women? In: G. Day \& C. Bloom (eds.) Perspectives on Pornography: Sexuality in Film and Literature. London: Palgrave MacMillan, pp. 101-109.

Berger, John 1972. Ways of Seeing. London: British Broadcasting Corporation \& Penguin Books.

Bordo, Susan 1999. The Male Body: A New Look at Men in Public and in Private. New York: Farrar, Straus and Giroux.

Dietze, Gabriele 1997. Hardboiled Woman. Geschlechterkrieg im amerikanischen Kriminalroman. Hamburg: Europäische Verlaganstalt.

Doane, Mary Ann 1985. Film und Maskerade: Zur Theorie des weiblichen Zuschauers. Frauen und Film, No. 38, pp. 4-19.

DorothyL. Mailing list. Available at http://www.dorothyl.com/, last accessed on 20 Nov 2009.

Doty, William G. 1996. Baring the Flesh: Aspects of Contemporary Male Iconography. In: B. Krondorfer (ed.) Men's Bodies, Men's Gods. Male Identities in a (Post-) Christian Culture. New York \& London: New York University Press, pp. 267-308.

Dyer, Richard 1986. 'Don't Look Now': Die Unstimmigkeiten des männlichen Pin-up. Frauen und Film, No. 40, pp. 13-19.

Evanovich, Janet 1994. One for the Money. New York: Scribner.

Evanovich, Janet 2001. Seven Up. London: Headline.

Evanovich, Janet 2002. Hard Eight. New York: St Martin's Press.

Evanovich, Janet 2005. Eleven on Top. New York: St Martin's Press. 
Evanovich, Janet \& Yalof, Ina 2006. How I Write. Secrets of a Bestselling Author. New York: St Martin's Press.

Frizzoni, Brigitte 2009. Verhandlungen mit Mordsfrauen. Geschlechterpositionierungen im "Frauenkrimi". Zürich: Chronos.

Gill, Rosalind 2001. Rethinking Masculinity: Men and Their Bodies. Session 1-6 (elearning seminar). (C) The London School of Economics and Political Science. Available at http://www.fathom.com/course/21701720/sessions.html, accessed on 20 Nov 2009.

Gill, Rosalind 2003. Power and the Production of Subjects. A Genealogy of the New Man and the New Lad. In: B. Benwell (ed.) Masculinity and Men's Lifestyle Magazines. Oxford \& Malden: Blackwell Publishing, pp. 34-56.

Gill, Rosalind; Henwood, Karen \& McLean, Carl 2003. A Genealogical Approach to Idealised Male Body Imagery. In: Paragraph Vol. 26, No. 1, 2, pp. 187-197.

Gill, Rosalind; Henwood, Karen \& Carl McLean 2005. Body Projects and the Regulation of Normative Masculinity. Body \& Society, Vol. 11, No. 1, pp. 37-62.

Gillis, Stacy \& Munford, Rebecca 2004. Genealogies and Generations: The Politics and Praxis of Third Wave Feminism. Women's History Review Vol. 13, No. 2, pp. 165182.

Gilmore, David D. 1994. The Beauty of the Beast: Male Body Imagery in Anthropological Perspective. In: M. G. Winkler \& L. B. Cole (eds.) The Good Body: Ascetiscism in Contemporary Culture. Binghamton, N. Y.: Vail-Ballou Press, pp. 191-214.

Harzewski, Stephanie 2006. Tradition and Displacement in the New Novel of Manners. In: S. Ferriss \& M. Young (eds.) Chick Lit: The New Woman's Fiction. London: Routledge, pp. 29-46.

Henderson, Lauren 1998. Freeze My Margarita. London: Hutchinson.

Henderson, Lauren 2001. Pretty Boy. London: Hutchinson.

Henderson, Lauren 2002 [1996]. Too Many Blondes. London: Hodder and Stoughton Ltd.

Kaplan, Megan 2002. Whatever happened to Diet Coke Hunk Lucky Vanous? CNN.com / Entertainment (2 Jul 2002). Available at http://archives.cnn.com/2002/SHOWBIZ/TV/07/02/watn.vanous, accessed on 20 Nov 2009.

Kaufmann, Kai 1997. Das Geschlechterverhältnis im amerikanischen Film noir. Alfeld \& Leine: Coppi-Verlag.

MacKinnon, Kenneth 1997. Uneasy Pleasures: The Male as Erotic Object. London: Cygnus Arts.

MacKinnon, Kenneth 2003. Representing Men. Maleness and Masculinity in the Media. London: Arnold.

Mayne, Judith 1993. Cinema and Spectatorship. New York \& London: Routledge.

Modleski, Tania 1982. Loving with a Vengeance. Mass-Produced Fantasies for Women. Hamden \& Connecticut: Archon Books.

Moore, Susanna 2003 [1995]. In the Cut. New York: Plume.

Mulvey, Laura 1988 [1975]. Visual Pleasure and Narrative Cinema. In: C. Penley (ed.) Feminism and Film Theory. New York: Routledge, pp. 57-68.

Neimark, Jill 1994. The Beefcaking of America. Psychology Today, Nov/Dec, pp. 32-39. Available also at http://www.psychologytoday.com/articles/pto-19941101000021.html, accessed on 20 Nov 2009. 
Pope Jr., Harrison G.; Phillips, Katharine A. \& Olivardia, Roberto 2000. The Adonis Complex. The Secret Crisis of Male Body Obsession. New York: The Free Press, Simon \& Schuster, Inc.

Radway, Janice 1991 [1984]. Reading the Romance. Women, Patriarchy, and Popular Literature. With a New Introduction by the Author. Chapel Hill \& London: The University of North Carolina Press.

Romance Writers of America, Inc. 2004. Romance-Fiction Sales Statistics, Reader Demographics, and Book-Buying Habits. Available at www.desertroserwa.org/ pdfs/StatisticsBrochure2004.pdf, accessed on 20 Nov 2009.

Saturday Night Fever 1997. Dir. John Badham. Paramount Pictures. Film.

Scherreiks, Sandra 2003. "Endlich der Richtige!” Diskurse über Männlichkeit und ihre Spiegelung in Trivialromanen zwischen 1973 und 1996. Deutscher Akademikerinnenbund. Wissenschaftliche Beiträge und Publikationen, 1. Münster u.a.: LIT Verlag.

Simpson, Mark 1994. Here Come the Mirror Men. The Independent, 15 Nov 1994. Available at http://www.marksimpson.com/pages/journalism/mirror_men.html, accessed on 20 Nov 2009.

Simpson, Mark 2003. Metrosexual? That Rings a Bell... Independent on Sunday, 22 June 2003. Available at http://marksimpson.com/pages/journalism/ metrosexual_ios.html, accessed on 20 Nov 2009.

Sonnet, Esther 1999. 'Erotic Fiction by Women for Women.' The Pleasures of PostFeminist Heterosexuality. Sexualities, Vol. 2, No. 2, pp. 167-187.

Thiel, Christian 1991. Liebe, Sex, Karriere. Die Modernisierung des trivialen Liebesromans. Mit einem Vorwort von Peter Nusser. Edition Philosophie und Sozialwissenschaften, Vol. 22. Hamburg \& Berlin: Argument-Verlag.

Thurston, Carol 1987. The Romance Revolution: Erotic Novels for Women and the Quest for a New Sexual Identity. Urbana \& Chicago: University of Illinois Press.

Urbauer, Anne 2005. Die Übersinnlichen. Der Mann entwickelt sich rasant. Nach dem Metrosexuellen wurde schon wieder eine neue Art entdeckt: Der Übersexuelle. NZZ am Sonntag, 6. November 2005.

Vance, Carol S. 1992 [1984]. More Danger, More Pleasure: A Decade after the Barnard Sexuality Confernece. In: C. S. Vance (ed.) Pleasure and Danger: Exploring Female Sexuality.London: Pandora Press, pp. xvi-xxviii.

Walton, Priscilla L. \& Jones, Manina 1999. Detective Agency: Women Rewriting the Hard-Boiled Tradition. Berkeley, Los Angeles \& London: University of California Press. 